\title{
MINORITY SAFEPACK - EGY TÖRTÉNET, AMELY TÚLMUTAT ÖNMAGÁN
}

\author{
Minority SafePack - A Story That Goes Beyond Itself
}

Benedek Zsombor ${ }^{1}$

\begin{abstract}
Absztrakt: A tanulmány a Minority SafePack elnevezésű európai polgári kezdeményezést és az annak keretet biztosító jogi környezetet vizsgálja meg. A tanulmány szerkezeti felépítése egységes keretet kíván adni a téma tárgyalásának. Az első rész azzal a több évtizedes európai diszkurzussal foglalkozik, amelynek köszönhetően létrejött az európai ügyekbe közvetlen állampolgári beleszólást biztosító jogintézmény, az európai polgári kezdeményezés. A tanulmány második részében egyrészt a Minority SafePack 10 éves történetét mutatjuk be kronológiai sorrendben, másrészt kitérünk az eddigi sikeres európai polgári kezdeményesekre és az arra adott bizottsági reakciókra, melyeket összevetünk a Minority SafePack-re adott bizottsági válasszal. Mindezek után a harmadik részben alátámasztjuk azt a feltevést, miszerint az ügyben eljáró uniós szervek több esetben politikai döntést hoztak, valamint azt, hogy a kezdeményezést nem kezelték úgy, mint egy összeurópai artikulálásra és aggregálásra tett kísérletet. Végezetül a tanulmány kitér a kisebbségvédelem biztonságpolitikai aspektusára és az ügy további hosszútávú lehetőségeire egyaránt.
\end{abstract}

Kulcsszavak: Minority SafePack, európai polgári kezdeményezés, kisebbségvédelem, Európai Unió, Európai Bizottság

Abstract: The study analyses the European Citizen's Initiative called Minority SafePack and its legal environment. The structure of the study provides the discussion of the topic with a coherent framework. The first part deals with the decades-long European discourse which led to the development of the European Citizens' Initiative, an institution giving direct channel to the European citizens in order to enter into dialogue with

${ }^{1}$ Benedek Zsombor, Nemzeti Közszolgálati Egyetem, kormányzás és vezetés mesterszakos hallgató.

ORCID: https://orcid.org/0000-0002-4140-0786 
European instituitions. The second part of the study presents the 10-yearold history of Minority SafePack in chronological order. Besides, it touches upon the other successful European Citizens Initiatives together with the reactions of the European Commission, so we can compare them to the response of the European Commission in the case of Minority SafePack. The third part of the study underscores the hypothesis that the relevant European institutions made political decisions in many cases and the initiative was not treated with due seriousness, albeit it attempted to spark a pan-European discussion and aggregation. Finally, the study examines the role of security policy and the further intricacies of the Minority Pack case.

Keywords: Minority SafePack, European Citizen's Innitiative, national minorities, European Union, European Commission

\section{BEVEZETÉS}

Jelen tanulmány a Minority SafePack - Egymillió aláírás az európai sokszínűségért elnevezésű európai polgári kezdeményezés kérdéskörét kívánja körbejárni. Annak ellenére, hogy az Európai Unió lakosságának 11 százalékát, azaz több mint 50 millió embert érint ${ }^{2}$, sok esetben nem kíséri kellő politikai, társadalmi, vagy éppen tudományos kíváncsiság, nyilvánosság. A Minority SafePack (a továbbiakban rövidítve: MSP) kezdeményezést bemutató tanulmány célja, hogy átfogó képet alkosson az európai polgári kezdeményezésekrôl, és ebben a keretben elhelyezve bemutassa a MSP jelentőségét.

A fentieknek megfelelően a tanulmány tartalmilag három nagyobb szerkezeti egységre tagolódik. Az első részben általánosságban bemutatásra kerül magának az európai polgári kezdeményezésnek (rövidítve: EPK) az intézménye, amely magával vonja a Lisszaboni Szerződés rövidebb áttekintését is. A második részben a MSP története kerül bemutatásra. A harmadik rész pedig kontextusba helyezi az eseményeket és az eredményeket, amikből a végén levonjuk a következtetéseket.

A tanulmány elsősorban arra keresi a választ, hogy az európai polgári kezdeményezés, mint az a jogintézmény, amely a demokráciadeficit orvoslására tett kísérletként értelmezhetô, beváltotta-e a hozzá füzött reményeket. A kérdést alapvetően a MSP keretein belül vizsgáljuk, de az

2 EPLÉNYI, 2013. 
elemzés során a többi sikeres kezdeményezésre is kitérünk. Emellett a tanulmány azt a hipotézist is górcső alá veszi, hogy az Európai Bizottság a MSP esetében az elutasítással vajon politikai döntést hozott-e, amely közvetlenül vagy közvetve, de több tízmillió uniós polgárra kihatással van. Végezetül harmadik hipotézisként a tanulmány azt állítja, hogy az uniós intézmények és az európai polgárok között demokrácia deficit van. ${ }^{3}$ Ugyanis az Európai Unió intézményei felett jellemzően nincs meg az uniós polgárok beleszólásának az az intézményesített formája, amellyel befolyást tudnának gyakorolni az ügyek folyamatára, mint ahogyan teszik ezt a saját nemzeti parlamentjeik és kormányaikkal szemben. Emellett, az ezekben a testületekben tisztséget viselő személyek mögött nincs meg az állampolgári felhatalmazás azon közvetlen formája, amely legitimációt jelenthetne. Ez pedig a korábban említett demokrácia deficit létrejöttéhez és mélyüléséhez vezethet.

Ahhoz azonban, hogy a kezdeményezés részleteibe belemerülhessünk, előtte szükséges megvizsgálnunk, hogy $\mathrm{mi}$ is az az európai polgári kezdeményezés, mi hozta azt létre, milyen körülmények között alkották meg, illetve milyen célok vezérelték azt a közösséget, amely életre hívta ezt az intézményt. Ezt követően a teljesség igényével kísérletet teszünk a kezdeményezés történetének kronologikus bemutatására.

A tanulmány utolsó részében az elemzés során addig felmerült kérdésekre keressük a választ. Mint ahogyan a cím is utal rá, ez nem csak egy kezdeményezés a sok közül. Nem csak a saját maga tárgykörében vetít elő messzemenő következtetéseket, hanem bizonyos események kontextusba helyezése után a jelenleg uralkodó európai diszkurzus sajátosságai is ki fognak rajzolódni.

\section{AZ EURÓPAI POLGÁRI KEZDEMÉNYEZÉS LÉTREJÖTTE ÉS AZ UNIÓS KISEBBSÉGVÉDELEM LEHETŐSÉGE}

Az európai polgári kezdeményezés jogintézményét a Lisszaboni szerződés teremtette meg. Éppen ezért elsőként magát a Lisszaboni Szerződést szükséges alaposabban szemügyre vennünk, amely 2009. december 1-jén lépett hatályba. Az elnevezés mögött valójában két szerződés áll, az Európai Unióról szóló szerződés (rövidítve: EUSz) és az Európai Unió múködéséről szóló szerződés (rövidítve: EUMSz). Az előbbi

\footnotetext{
3 ÁSVÁNYI, 2011.
} 
az 1992-ben aláírt Maastrichti Szerződésen alapszik, amely az Európai Uniót létrehozó szerződést is tartalmazta (a későbbi szerződések - lásd alább - ezt tovább módosították). Utóbbi pedig az 1957-ben aláírt Európai Gazdasági Közösség (EGK) létrehozásáról szóló Római Szerződésen alapul, amelyet a későbbiek során a Maastrichti, majd az 1999. május 1-jén hatályba lépett Amszterdami és a 2003. február 1-jén hatályba lépett Nizzai Szerződések további módosításai követtek.

A gondolat mögött, aminek az eredménye a Lisszaboni Szerződés lett, eredetileg más szándékok húzódtak. Ugyanis a szerződés előkészítése alkotmányozó munka formájában jelent meg 2001 végén (Alkotmányszerződés). Ezt a munkát 2002-ben és 2003-ban a direkt az alkotmány kidolgozására létrehozott Európai Konvent ${ }^{4}$ vitte tovább, amelyet 2001 decemberében az Európai Tanács laekeni csúcson ${ }^{5}$ elfogadott nyilatkozatának eredményeként alkottak meg. Annak ellenére, hogy mindenkori szóhasználat alkotmányként hivatkozik rá, ez egy nemzetközi szerződés volt, amelynek a végleges verzióját 2004. október 29-én írtak alá az állam- és kormányfők Rómában. Mivel ez egy nemzetközi szerződés volt, ezért annak a hatályba lépéséhez nem volt elég az országvezetők aláírása, hanem külön-külön minden egyes országban ratifikációra volt szükség, összesen 25-re. Azonban a 25 tagállamból kettőben, Franciaországban és Hollandiában népszavazás ${ }^{6}$ útján elutasították az állampolgárok 2005 májusában és júliusában a nemzetközi szerződés saját belső jogrendszerükbe történő átültetését. Az elutasítás oka, hogy az állampolgárok féltek attól, hogy ha egy nemzetközi szervezetnek alkotmányt adnak, akkor azzal a saját országuk szuverenitását veszélyeztetik. Ez egy olyan hirtelen mélyítése lett volna az integrációnak, amely alapvetôen változtatta volna meg az Európai Unió és a tagállamok viszonyrendszerét és az addigi, inkább kormányközi együttműködésre alapozó rendszert szupranacionális irányba tolta volna el.

Ennek a következtében az Európai Tanács kétéves „gondolkodási időszak" bevezetése mellett döntött. Ez akkoriban visszalépésnek számított az integrációt mélyíteni kívánó csoportok számára, ugyanis egy több éves bizakodásra okot adó folyamat végén érkezett az uniós polgároktól a jelzés, amely megálljt parancsolt az egységes alkotmánynak. ${ }^{7}$ Érvelésük szerint az

\footnotetext{
${ }^{4}$ Az Európai Tanács által létrehozott nemzetközi konferencia, amelyet az Európai Unió jövőjét illető legfontosabb kérdések megvitatására és döntés-előkészítésre hoztak létre

${ }^{5}$ EUROPEAN COUNCIL, 14 AND 15 DECEMBER 2001.

${ }^{6}$ Európai PARLAMENT, EuróPAi AlKOTMÁNY - ÁtTEKINTÉs, 2005.

${ }^{7}$ STIBBE - TANER, 2019.
} 
új alkotmány átláthatóbbá és hatékonyabbá tette volna az EU-t, ami fokozni tudta volna a fejlődést. Mindemellett az addig széttöredezetten külön-külön szerződésekben megfogalmazott alapvető értékek, célok és hatáskörök egységbe foglalása hozzájárult volna az Európai Unió hatékonyabb fellépéséhez a nemzetközi hatalmi szereplők között. ${ }^{8}$

Azonban az általános érvek mellett, amelyek jellemzően a hatékonysággal és az átláthatósággal foglalkoznak, megtalálható a demokráciadeficit 1988-ból ${ }^{9}$ származó problémaköre is. A szóban forgó deficit akkor keletkezik, amikor az egyes törvények és határozatok meghozatalának joga a közösséget alkotó nemzeti parlamentektôl átkerül az Európai Unió hatáskörébe, melynek következtében az állampolgárok szavazatai leértékelődnek nemzeti szinten úgy, hogy az nincs ellensúlyozva az EU szintjén. A demokráciadeficit jelensége mindmáig meghatározó eleme az Európai Unió megítélésének. Ennek egyik legfőbb oka, hogy az átlag uniós polgár számára az Európai Unió intézményrendszere követhetetlen és bonyolult. Nem tud az uniós intézményekre úgy tekinteni, mint a saját hazájának a kormányára. Másrészt az sem segít a problémán, hogy maga a döntéshozatali mechanizmus sem demokratikus és nincsenek beépítve olyan intézményes ellensúlyok, amelyek biztosítékként szolgálnának az önkényes döntéshozatal kizárásának. Ezeket az állításokat támasztják alá a részvételi arányok is az öt évente ismétlődő uniós parlamenti választásokon is, amelyeken jellemzően a szavazásra jogosult lakosság csupán 40-50\%-a járul rendszeresen az urnákhoz.

Mindazonáltal a tervezett változtatások jelentősek lettek volna. Maga a szerződés egy kartális materiális alkotmányként ${ }^{10}$ jelent volna meg. Kartális, mivel egy olyan meghatározott dokumentumról van szó, amely mind formai, mind megalkotásának módjában eltér a többi törvénytől, valamint a jogi hierarchia legfelső csúcsán helyezkedik el. Materiálisnak is tekinthető, hiszen tényleges és részletes magatartási szabályokat is tartalmaz. Magában foglalta volna az Európai Unió alapvetéseit, célkitűzéseit, az Alapjogi Chartát, ami minden tagállamra kötelező érvényű, valamint az egyes közösségi szakpolitikákra vonatkozó rendelkezéseket is tartalmazott volna. Továbbá létrehozták volna a közös külügyminiszteri posztot, aminek a hatáskörében eljáró személy egységesen léphetett volna fel a nemzetközi szereplők között, az Unió képviseletében. Megnövekedett volna a Parlament

\footnotetext{
${ }^{8}$ MagYarKollÉGiUm.HU

9 ÁsVÁNYI, 2011.

10 ARATÓ - LUX, 2012.
} 
szerepe azáltal, hogy az európai törvények 95\%-a együttdöntési eljárás keretében került volna meghozatalra, amelynek neve általános törvényhozási folyamat lett volna. Változott volna az Európai Bizottság összetétele, ami megszüntette volna az „egy ország - egy biztos” elv szerint meghatározott formulát és helyette a biztosok száma a tagállamok 2/3-ának számára csökkent volna. ${ }^{11}$ A tanulmány tárgya szempontjából az alkotmánytervezet 47. cikke az igazán érdekes. E részlet a korábban taglalt demokráciadeficitet próbálja megoldani azáltal, hogy közvetlen részvételt hirdet az uniós polgárok számra az Európai Unió ügyeibe. Az alkotmány szerint az intézmények a megfelelő eszközöket kell biztosítsák arra, hogy az uniós polgárok és az érdekképviseleti szervezetek az Unió bármely tevékenységéről véleményt nyilváníthassanak. Ennek az egyik megjelenési formája az európai polgári kezdeményezés jogintézményének a létrejötte. Erre a gondolatra a tanulmány későbbi részében még visszatérünk.

A fentiek ismertetését azért tartottuk fontosnak, mivel nem pusztán az Alkotmányszerződés elfogadására került volna sor, hanem az európai integráció további mélyítésére vonatkozó szándékok is összecsaptak. Hiszen egy Európai Alkotmány hatalmas és nagyon nehezen visszafordítható lépés lenne a föderális Európa gyakorlati megvalósulása felé. Azonban a kontinens történelmi hagyományai és az alkotmányok magától értetődő szuverén jellegük miatt ez látszólag nem valósulhatott meg. Egy alkotmány létrehozásához szükség van a népre, vagyis a „politikai testre”. Az egyes országok esetében ez nem jelent problémát, hiszen ott az alkotmányozó, a nép meg is formálja és alá is veti magát annak. Azonban az Európai Unió esetében a politikai test az egyes tagállamok kormányzatát és parlamentjeit jelenti, ami nem biztosít kellő legitimációt. Az európai démosz nélkül ez a legitimitás deficit nem is tud megoldódni, ami azt irányozza elő, hogy azokra a kezdeményezésekre és mechanizmusokra lenne szükség, amelyek nemzetekre és nemzetek közötti kooperációra épülnek. A föderalizmusnak a jelenlegi európai kultúrában és politikai berendezkedésben nincsen tere. $\mathrm{Ha}$ ez megvalósulna akkor a jogalkotást egyedül a Parlament végezhetné és a Tanács, amely ma tagállami érdekeket jelenít meg teljesen elveszítené ezt a funkcióját. $^{12}$

11 Európai PARLAMENT, AZ EURÓPAI ALKOTMÁNYT LÉTREHOZÓ SZERZŐDÉS TERVEZETE

12 MARJÁN - BOROS, 2017. 
Az említett gondolkodási időszakot követően a 2007-es márciusi Berlini Nyilatkozat ${ }^{13}$ alapján az Európai Tanács elfogadta a portugál soros elnökség részletes megbízását a tervezet feltámasztására. Ezen a ponton szükséges visszautalni a Lisszaboni Szerződés által módosított, korábban említett két szerződésre. Ugyanis a korábban megfogalmazott alkotmány szövegét a kudarcok hatására nem merték megkísérelni újból ugyanolyan módszerrel végig vinni. Evégett egy sajátos jogi megoldással éltek, amelynek kizárólag politikai okai voltak. Ahhoz, hogy a korábbi tartalom megmenekülhessen, az tűnt a legkézenfekvőbb és legegyszerűbb megoldásnak számukra, hogy egy új szerződés létrehozása helyett „mindössze” a szerződéseket módosítják. Ennek köszönhetően az Alkotmányszerződés eredeti tartalmának túlnyomó többségét megmentették. ${ }^{14}$

Az Európai Unió létrehozásáról szóló szerződést 62 esetben, az Európai Közösségeket létrehozó szerződés 295 esetben lett módosítva. Előbbit az Európai Unióról szóló szerződésre (rövidítve: EUSz), míg utóbbit az Európai Unió Múködéséről szóló Szerződésre (rövidítve: EUMSz) nevezték át. Ezáltal a korábbi alkotmány szövegtervezet tartalmának 80-90\%-a érvénybe léphetett. Mindezeknek az eredményeként a módosított szerződéseket 2007. december 13-án az Európai Tanács Lisszabonban aláirta és ezt követően a tagállamok általi ratifikációra is sor került. Így 2009. december 1-jén hatályba léphetett a tetemes változásokat eszközlő Lisszaboni Szerződések. Ilyen változtatás többek között ${ }^{15}$, hogy megnövekedett a minősített többségi szavazások száma az EU Tanácsában, megszűnt a korábbi pillérrendszer, amely a maastrichti szerződéssel lépett hatályba, valamint új tisztségek jöttek létre, mint amilyen az Európai Unió külügyi és biztonságpolitikai főképviselői poszt vagy az Európai Tanács elnöki pozíció. Ez utóbbi jelenti a leglátványosabb változást, ugyanis a két és fél évre választott Elnök legfontosabb szerepe mellett, hogy építse a nemzetközi kapcsolatokat, létrejött szimbolikusan egy olyan tisztség, amelynek betöltője egy személyben képes képviselni az Európai Unió mind a 27 tagállamát. $^{16}$

$\mathrm{Az}$ uniós polgárok közvetlen részvételének elősegítésére és a demokráciadeficit csökkentésére az európai polgári kezdeményezést az

13 BÁLINT, 2009.

14 DiENES-OEHM ÉS MTSAI, 2014.

15 MEDINA, 2011.

16 PARLAMENT, 2021. 
EUMSz második rész „A megkülönböztetés tilalma és az uniós polgárság” címú fejezetének 24. cikke vezeti be. Ez elôször utal az EUSz 11. cikkére. A 11. cikk szerint az alkotmánytervezet 47 . cikkével összhangban azt mondja ki, hogy az uniós intézmények megfelelő eszközökkel kell biztosítsák, hogy az állampolgárok és érdekképviseleti szervezetek az Európai Unió bármely tevékenységéről véleményt nyilváníthassanak. Mindezt úgy, hogy az intézmények az érdekképviseleti szervezetekkel és a civil társadalommal nyílt és átlátható párbeszédet kell fenntartsanak. Annak érdekében, hogy ez meg tudjon valósulni az Európai Bizottság széles körű konzultációkat kell folytasson. Továbbá itt jelenik meg először az első számszerű követelmény, miszerint egy ilyen kezdeményezéshez legalább egymillió uniós polgár támogatására van szükség.

Ezt követően az EUMSz 24. cikk hivatkozik az EUSz 227. és 228. cikkére. A 227. cikk értelmében bármely uniós polgár, valamint valamely tagállamban lakóhellyel vagy székhellyel rendelkező természetes jogi személy egyénileg és más polgárokkal együttesen egyaránt petíciót nyújthat be az Európai Parlamenthez, az Európai Unió tevékenységi területéhez tartozó olyan ügyekben, amely őt vagy őket közvetlen érintetté teszik.

A 228. cikk értelmében minden uniós polgárnak joga van hivatkozott cikkben intézményesített ombudsmanhoz fordulni az uniós szervek vagy hivatalok tevékenysége során felmerülő hivatali visszásságokra vonatkozó panaszok esetében, kivéve az Európai Unió Bíróságának igazságszolgáltatási hatáskörével kapcsolatban.

Az európai polgári kezdeményezésre vonatkozó részletszabályokat az Európai Parlament és a Tanács 211/2011/EU rendelete ${ }^{17}$ tartalmazza. Ezt 2011. február 16-án írták alá, majd ezt követően a rendelet 2012. április 1-én lépett hatályba. A 23 cikkből és 7 mellékletből álló rendelet az, amely alapján a ma ismert formában élhetnek az uniós polgárok a kezdeményezés jogával. Előbbiek részletesen ismertetik magát a folyamatot, az állampolgárok feladatait és lehetôségeit, az érintett intézmények szerepét, végül a technikai részleteket. A mellékletek pedig tartalmazzák az egyes tagállamokra vonatkozó küszöbértékeket ${ }^{18}$ és az összes olyan formanyomtatványt, amelyre a kezdeményezés valamely szakaszában szükség lesz.

\footnotetext{
17 Az Európai Parlament És a TANÁcs, 2011.

18 Egyrészt tartalmazza a tagállamonkénti aláirók minimum számát, másrészt pedig a kezdeményezés nyilvántartásba vételéhez szükséges formai és karakterszámbeli megkötéseit.
} 
Mindezt a dokumentumot kiegészíti még az Európai Bizottság $1179 / 2011 / \mathrm{EU}$ végrehajtási rendelete ${ }^{19}$, amely az online gyújtési rendszerekre vonatkozó technikai előírásokat tartalmazza.

Magyarország belső jogrendszerébe történő átültetését a 2013. évi CCXXXVIII. törvény ${ }^{20}$ „Az európai polgári kezdeményezés” nevezetű IV. fejezete vezeti be.

Mindezek ismeretében beszélhetünk most már az európai polgári kezdeményezés konkrét folyamatáról, amely hét lépésből áll. ${ }^{21}$

Az első lépés, hogy egy polgári bizottságot kell alakítani. Ehhez szükség van hét különböző uniós országban lakóhellyel rendelkező személyre. A parlamenti képviselők nem számítanak bele a polgári bizottság szükséges minimum létszámába és szervezetek nem hozhatnak létre polgári bizottságokat, azonban támogathatják azokat.

Második lépésként a kezdeményezést nyilvántartásba kell vetetni. A kezdeményezéseket az Európai Bizottság hagyhatja jóvá. Ezeket az EU 24 hivatalos nyelvének bármelyikén be lehet nyújtani. A kötelező elemek: a kezdeményezés címe, témájának rövid összefoglalója, hivatkozás az uniós szerződésekre és a polgári bizottság elérhetôségei. Ezt követően az Európai Bizottság két hónapon belül tájékoztatást ad arról, hogy a kezdeményezés megfelel-e az alapvető követelményeknek. ${ }^{22}$ Ezeket a kezdeményezéseket online nyilvántartásba is közzéteszik. Elutasítás esetén az Európai Bizottság három hónapon belül köteles közleményeben a polgári nyilvántartásról alkotott jogi és politikai következtetéseit összefoglalni, ahogyan az elutasítás okát is tisztáznia kell.

Harmadik lépésként elkezdődhet a támogató aláírások gyűjtése, amire egy év áll a szervezők rendelkezésére. Ez online és papíralapon egyaránt történhet. Ahogy korábban említettük, egymillió támogató aláírásra van szükség. Azonban ezeket nem elég egyetlen országban összegyújteni. Az aláírásoknak az uniós országok legalább egynegyedéből kell származnia. Mivel az Egyesült Királyság kilépése óta 27 tagállam van, ezért legalább hét országban kell az aláirásokat összegyújteni. Az egyes országokban kötelezően összegyűjtendő minimum aláírások egy sajátos kvóta szerint vannak meghatározva. Ennek a számítási módja, hogy az adott ország

\footnotetext{
19 BizotTś́G, 2011.

20 2013. ÉVI CCXXXVIII. TÖRVÉNY A NÉPSZAVAZÁS KEZDEMÉNYEZÉSÉRŐL, AZ EURÓPAI POLGÁRI KEZDEMÉNYEZÉSRŐL, VALAMINT A NÉPSZAVAZÁSI ELJÁRÁSRÓL

${ }^{21}$ EURÓPAI POLGÁRI KEZDEMÉNYEZÉS

22 Polgári bizottság helyes összetétele, valamint a felsorolt kötelező elemek megléte
} 
európai parlamenti képviselőinek számát meg kell szorozni 750-nel. Az így kapott eredmény lesz az a szükséges minimum aláírási szám, amely szükséges, hogy egy ország egyike legyen az érvényes aláirást gyüjtőknek. Ennek a kvótának a kiszámítása így a mindenkori Európai Parlament összetételének a függvénye. E számítási módnak megfelelően Magyarországon 15.750, Romániában 25.500, Szlovákiában 11.250, Németországban 72.000, Franciaországban 63.000 és Lengyelországban 39.750 aláirásra van szükség.

Negyedik lépésben, ha összegyưlt az egymillió, vagy több aláíás akkor azokat valamennyi érintett uniós ország hatóságai számára el kell küldeni. $\mathrm{Az}$ ő feladatuk lesz az aláírások hitelességének az ellenőrzése - erre legfeljebb 3 hónap áll rendelkezésükre - aminek a végeredményeként egy igazolást is ki kell állítsanak.

Ötödik lépésként ezt követôen a kezdeményezést be kell nyújtani az Európai Bizottsághoz. Ezzel egyidőben pedig nyilvánosságra kell hozni minden olyan anyagot, amely a kezdeményezéshez füződő anyagi és természetbeni támogatásokkal függ össze. Az Európai Bizottság minden adatot közzé kell, hogy tegyen a honlapján.

Ezután hatodik lépésként az Európai Bizottságon van a sor, hogy 3 hónap alatt alaposan megvizsgálva a kezdeményezést, levonja a megfelelő jogi és politikai következtetéseit. Ezen idôtartam alatt az Európai Bizottság lehetőséget biztosíthat a szervezőknek arra, hogy kezdeményezésüket az Európai Parlamentben tartott közmeghallgatáson ismertessék.

Végezetül, a hetedik lépésként, az Európai Bizottságnak tájékoztatást kell adnia a következő lépésekről és az esetlegesen kilátásba helyezett intézkedésekről. Végeredményként az Európai Bizottság új jogszabályra irányuló javaslatot terjeszthet elő és azt jóváhagyás céljából tovább küldheti az Európai Parlamentnek és a Tanácsnak.

A demokráciadeficit megoldása szempontjából komoly probléma, hogy ha az Európai Bizottság elutasítja a kezdeményezést, akkor a kezdeményezőknek és így az uniós polgároknak nincsen a rendszerbe becsatornázott döntés-megfellebbezési lehetőségük. Ez az Európai Bizottság monopol jellegét erősíti, ami ellentétes az eredeti szándékokkal. Ez egy konstrukciós hiba, mivel az Európai Bizottság egy szupranacionális szerv, kizárólag az uniós érdekek előmozdítása érdekében működik. ${ }^{23}$ Azáltal pedig, hogy a leginkább közvetlen-állampolgári intézmény végső

23 BLUTMan, 2020. 
stádiumának színhelye az Európai Bizottság, előrevetíthető az érdekek egyoldalú érvényesítésének feltételezése. Ez pedig felveti annak a gyanúját, hogy a szerződés kidolgozását irányító európai elit csupán egy látszatintézkedésként, illetve látszatintézményként tekintettek az európai polgári kezdeményezésre, amellyel az alapvetően erősödő lopakodó hatáskörnövelésről szerették volna a figyelmet elterelni. Ha a szándékaik valóban a demokrácia deficit megoldására irányultak volna, akkor a nemzetek által delegált Európai Parlamentnek nem csupán véleményezési szerepe lenne. Ez utóbbira - ahogy majd látni fogjuk - a MSP jó példát szolgáltat, hiszen az Európai Parlament támogató határozata ellenére az Európai Bizottság végül nem kezdeményezett jogszabályt az ügyben.

Mindezek ellenére a MSP szervezőinek ez a jogintézmény több szempontból is vonzó volt, minden előrevetíthető problémájával összességében. Egyrészt az a tény, hogy az uniós jogalkotási kezdeményezésben egyedülálló jogkörökkel bíró Európai Bizottság korábban sosem foglalkozott az őshonos nemzeti kisebbségek védelmével. Azáltal, hogy a megfelelő aláirás összegyűjtésével kilátásba helyezhetôvé került ennek a változtatása, már kellő motivációt jelentett a szervezők számára. Emellett, mint ahogy a témában releváns tanulmány ${ }^{24}$ is rámutat, a kisebbségvédelmi kezdeményezések pozitív hatást tudnak gyakorolni a nemzeti kisebbségek védelmével kapcsolatosan tapasztalható politikai fenntartások enyhítésére és megváltoztathatja az elutasító politikai magatartást is. Mindezek mellett a szervezők számára a leginkább motiváló tényező, amely egyben a kezdeményezés legitimitását is alátámasztja az az érintettek köre. Mint ahogyan a tanulmány korábban megjegyzi, az Európai Unióban 50 millió olyan személy él, amely valamely nemzeti kisebbség tagjának vallja magát. Tekintettel arra, hogy az Európai Unió lakossága 2021-ben 446 millió fó, ez azt jelenti, hogy minden kilencedik ember javát szolgálná a kezdeményezés.

Azonban hátráltató tényezőként volt kezelendő az a tény, hogy az Európai Uniónak nincsen kisebbségvédelmi dimenziója, vagyis nincs hatásköre kisebbségvédelem területén direkt jogszabályalkotásra. ${ }^{25} \mathrm{Ez}$ nem jelenti azt azonban, hogy az Európai Bizottság esetleges szándékát az eszközök hiánya gátolná. Ugyanis létezik három terület, amely a kisebbségvédelmi törekvések érvényesítésére lehetôséget $a d{ }^{26} \mathrm{Az}$ első a

\footnotetext{
24 TÁRNOK, 2020.

25 TÁRNOK, (dátum nélkül)

${ }^{26}$ MANZINGER - VINCZE, (dátum nélkül)
} 
tagállamok feletti szabályozás és minimumkövetelmények meghatározása. A második a nyelvi sokszínúség iránti tényleges figyelemfelkeltés. A harmadik pedig a tagállamok belső jogszabályainak számonkérése, a jogállamiság érvényesítése.

\section{A MINORITY SAFEPACK KEZDEMÉNYEZÉS TÖRTÉNETE}

Mindezek ismeretében most már rátérhetünk magának a MSP kezdeményezésnek az ismertetésére, valamint az abban szerepet vállaló Federal Union of European Nationalities (a továbbiakban rövidítve: FUEN, magyar fordításban: Európai Nemzetiségek Föderatív Uniója) szerepére.

A FUEN az európai őshonos és nemzeti kisebbségek, valamint nyelvcsoportok érdekképviseleti szervezete, egyben a legnagyobb ernyőszervezete a tárgykörnek Európában, a maga 35 államból származó 107 tagszervezetével. $^{27}$

A szervezet története ${ }^{28}$ az 1949-es évre nyúlik vissza, amikor is november 20-án Párizsban a Palais de Chaillot-ban megalakult. Az akkor megszervezett „Nemzetiségek Kongresszusán” közel 200-an vettek részt. Az alapvető szándék az volt, hogy az akkor megalakuló Európa Tanácsot létrehozó eszmék szerint fognak működni. Az első időszakukban regionalista elvek szerint múködtek, azonban hamar ráeszméltek, hogy sokkal szélesebb az a terület, amely érdekképviseletét el szeretnék látni így fokozatosan a FUEN az európai őshonos nemzeti és nyelvi kisebbségek ernyőszervezetévé vált. Az első évtizedekben a tevékenységük elsősorban a folytonos elismerésért és az erőforrások megszerzéséért folytatott küzdelemben merült ki. A szervezet számára kulcsfontosságú volt az 1989es év amikor is a FUEN konzultatív státust és elismerést nyert az Európa Tanácsban. $^{29}$ Az 1990-es évektől kezdődően a kelet európai rendszerváltások következtében az alapvetően nyugati súlypontú szervezet összeurópaivá válik azáltal, hogy bekapcsolódik a Kelet-Európában élő kisebbségek jogainak érvényesítésébe. ${ }^{30}$

\footnotetext{
${ }^{27}$ FUEN (1)

${ }^{28}$ FUEN (2)

${ }^{29}$ FUEN (2)

30 A Kelet-Európai rendszerváltás után csatlakozott például a: felvidéki Magyar Közösség Pártja és a Sepsiszentgyörgyi székhelyű Székely Nemzeti Tanács.
} 
A szervezet következő igazán nagy sikere 2017-ben következett be, amit a MSP kapcsán értek el, azonban erről később lesz szó a tanulmányban.

Amikor tehát hatályba lépett az európai polgári kezdeményezés a FUEN szinte azonnal lépésre szánta el magát és a Romániai Magyar Demokrata Szövetséggel (rövidítve: RMDSZ), a Dél-Tiroli Néppárttal (rövidítve: SVP), valamint az Európai Nemzetiségek Ifjúságával (rövidítve: YEN) összefogva megtette a szükséges lépéseket és elindulhatott a kezdeményezés előkészítése. A polgári bizottságot hét személy alkotta: Hans Heinrich Hansen, Kelemen Hunor, Jannewietske Annie De Vries, Anke Spoorendonk, Alois Durnwalder, Karl-Heinz Lambertz és Valentino Inzko. A kezdeményezés célkitűzése az volt, hogy javítsa a nemzeti és nyelvi kisebbségekhez tartozó személyek védelmét és erősítse az Európai Unió kulturális és nyelvi sokszínúséget. Összességében nyolc szakpolitikai területen fogalmaztak meg 11 javaslatot, többek között az audiovizuális médiaszolgáltatásról szóló irányelvvel vagy éppen a támogatási programok módosításával kapcsolatosan úgy, hogy azok elérhetőek legyenek a kisebbségi nyelvet beszélők számára is. ${ }^{31}$ 2013. július 16-án benyújtották a kezdeményezést az Európai Bizottsághoz, hogy vegye azt nyilvántartásba. Azonban 2013. szeptember 13-án az Európai Bizottság elutasította a kezdeményezést, mert úgy ítélte meg, hogy a javaslatok egyike sem tartozik az Európai Unió szabályozási területébe és utalt arra, hogy sem az EUSz sem pedig az EUMSz nem jogosítja fel e területnek a szabályozására. ${ }^{32}$ A kezdeményezésben aktívan résztvevő egyik támogató, az RMDSZ már ekkor kijelentette ${ }^{33}$, hogy az Európai Bizottság politikai döntést hozott. Azonban, ha eltekintünk a témakör politikai és érzelmi vetületétől, akkor az elutasítás egy tágabb kontextusban is problémát vetít elő, ahogyan erre Tárnok Balázs is felhívja a figyelmet. Szerinte ugyanis ${ }^{34}$ a kezdeményezés kategorikus elutasítása negatív hatással lehet a későbbi kisebbségvédelmi kezdeményezésekre, ráadásul ez a gyakorlat könnyen példaként szolgálhat nem csak uniós szinten a további kezdeményezések kapcsán, hanem az egyes tagállamok negatív magatartását is előidézheti.

\footnotetext{
${ }^{31}$ FUEN (3)

32 A „Minority SafePack - one million signatures for diversity in Europe” című európai polgári kezdeményezésre irányuló javaslat nyilvántartásba vétele iránti kérelmet elutasító, 2013. szeptember 13-i C (2013) 5969 final bizottsági határozat

33 GYERGYAI - VÁSÁRHELYI-NYEMEC, 2013.

34 TÁRNOK, 2020. 14.o.
} 
Mindezek következményeként a szervezők felkeresték az Európai Unió Törvényszékét és megtámadták az elutasító határozatot, mondván, hogy az Európai Bizottság nem vette figyelembe a kezdeményezés mellékleteként benyújtott intézkedéscsomagot, ahogyan a védzáradékot sem.

A bírósági perbe 2014-ben belépett Szlovákia és Románia a MSP elleni oldalra és Magyarország pedig a kezdeményezést támogatók oldalára. Románia és Szlovákia azt nehezményezte a kezdeményezés kapcsán, hogy az Európai Bíróság joggyakorlata révén szerintük Uniós hatáskörbe kerültek volna a kisebbségekhez tartozók jogainak a védelme, ami az országaik szuverenitását veszélyeztetné. ${ }^{35}$ Ezzel szemben Magyarország számára egyértelmű volt a támogató magatartás, hiszen a kezdeményezés nagyban hozzájárulna a külhoni magyarság életkörülményeinek javulásához.

Az ügyben végül a MSP kezdeményezésnek igazságot szolgáltatott a Törvényszék és ennek hatására 2017. március 29-én az Európai Bizottság határozatában ${ }^{36}$ ismertette, hogy a 2017. február 3-ai T-646/13. sz. ügyben a bíróság hatályon kívül helyezte a korábbi 2013. szeptember 13-ai C (2013) 5969. számú határozatot, ${ }^{37}$ amellyel korábban az Európai Bizottság a kezdeményezést elutasította. A Törvényszék érvelése szerint az Európai Bizottság azáltal, hogy nem teljesítette indoklási kötelezettségét a szervezők irányába, elzárta annak a lehetőségét, hogy beazonosíthatóvá váljanak azok a területek és javaslatok, amelyek az Európai Bizottság szerint kívül esnek az Európai Unió jogalkotási hatáskörén. Evégett sem a szervezők nem tudták vitatni az értékelést, sem pedig a Törvényszék nem tudott felülvizsgálatot gyakorolni az Európai Bizottság értékelésének jogszerűsége felett. ${ }^{38}$

A 2013-ban benyújtott polgári kezdeményezés 11 konkrét uniós jogi aktust jelölt meg, amely aktusoknak az adott területen jogszabályi változtatásokon kellett volna, hogy átesniük. Az Európai Bizottság 2017. március 29-i határozata ebből 9-et hagyott jóvá, amelyek a következők:

\footnotetext{
35 FELVIDEK.MA, 2014.

36 A Bizottság (EU) 2017/652 határozata (2017. március 29.) a „Minority SafePack egymillió aláírás a sokszínű Európáért” elnevezésű javasolt polgári kezdeményezésről

${ }^{37}$ A „Minority SafePack - one million signatures for diversity in Europe” című európai polgári kezdeményezésre irányuló javaslat nyilvántartásba vétele iránti kérelmet elutasító, 2013. szeptember 13-i C (2013) 5969 final bizottsági határozat.

38 VARGA - TÁRNOK, 2017.
} 
1. Tanácsi ajánlás a kulturális és nyelvi sokszínűség védelméért és előmozdításáért az Európai Unióban.

2. Európai parlamenti és tanácsi határozat vagy rendelet, amelynek célja a támogatási programok módosítása úgy, hogy azok a kis régiókban élők számára és kisebbségi nyelvet beszélők számára is elérhetőek legyenek.

3. Európai parlamenti és tanácsi határozat vagy rendelet, amely olyan nyelvi sokféleségi központ felállítására irányul, amely a regionális és kisebbségi nyelvek fontosságát hangsúlyozza, és a sokféleséget minden szinten népszerűsíti, továbbá amelyet alapvetően az Európai Unió finanszíroz.

4. Strukturális alapok feladataira, elsődleges célkitűzéseire és megszervezésére alkalmazandó általános szabályok oly módon történő kiigazítására vonatkozó rendelet, amely figyelembe veszi a kisebbségek védelmét és a kulturális és nyelvi sokféleség előmozdítását, amennyiben a támogatandó fellépés hozzájárul az Európai Unió gazdasági, társadalmi és területi kohéziójának erôsítéséhez.

5. Európai parlamenti és tanácsi rendelet, amelynek célja a Horizont 2020 programra vonatkozó rendelet módosítása azon hozzáadott érték kutatásának javítása érdekében, amelyet a nemzeti kisebbségek, valamint a kulturális és nyelvi sokszínúség az uniós régiók gazdasági és társadalmi fejlődéséhez adhat.

6. Uniós jogszabályok módosítása a hontalanok és az uniós polgárok közötti szinte egyenlő bánásmód biztosítása érdekében.

7. Az egységes szerzői jogra vonatkozó rendeletek módosítása oly módon, hogy a szerzői jog tekintetében az egész Európai Unió belső piacnak legyen tekinthető.

8. 2010/13/EU irányelv módosítása az audiovizuális szolgáltatások és a sugárzott tartalmak vétel szabadságának a nemzeti kisebbségek által lakott régiókban való biztosítása érdekében.

9. Tanácsi rendelet vagy határozat a nemzeti kisebbségeket és kultúrájukat támogató projekteknek az EUMSz 108. cikkének 2. bekezdése szerinti eljárás tekintetében alkalmazandó csoportmentessége érdekében.

Az Európai Bizottság 2017. március 29-i határozatának az 1. cikkének (1) bekezdése kimondja, hogy a „Minority SafePack - egymillió aláirás a sokszínú Európáért" elnevezésű kezdeményezés a fent említett kilenc ponttal nyilvántartásba vételre kerül. A hazai tudományos élet szereplői üdvözölték az újbóli nyilvántartásba vételt. Tárnok Balázs doktori értekezésében úgy fogalmazott, hogy „a törvényszék első iz̧ben adott igazat egy 
európai polgári kezdeményezés szervezóinek, a Bizottság kezdeményezés bejegyzését elutasitó határozatával szemben indított perben". "Természetesen a FUEN is üdvözölte a döntést és az ezt követő kiadványában felhívja a figyelmet az ügy jelentôségére. ${ }^{40}$ Megemlíti, hogy a kisebbségvédelem nem egy háttérbe szorítható politikai téma, hiszen az Európai Unió tagállamává válni kívánó országok csatlakozási feltételeként meghatározott Koppenhágai kritériumok $^{41}$ is kitérnek a kisebbségek védelmére, mint kötelező elemre.

Mivel ez a határozat 2017. április 3-án lépett hatályba, így ettől a dátumtól kezdődően meg lehetett kezdeni az aláirásgyüjtést. Ez sikeresen megtörtént, a kezdeményezés 2018. április 3-áig összegyüjtött 1.123 .422 aláírást, mindezt 11 tagállamból. ${ }^{42}$ Az aláirások tekintetében kiemelten jól szerepelt Magyarország és a Romániában élő magyarság. E két közösségből származik az 1.123.422 aláírásnak a 70 százaléka, pontosabban 782.557. E két ország mellett érdemes még megemlíteni Olaszországot, Spanyolországot és Szlovákiát, ahonnan együttesen több, mint 185 ezernyi aláírás gyűlt össze. Ahogyan egy tanulmány is rámutat ${ }^{43}$, jellemzően azok a kezdeményezések tudnak sikeresek lenni az aláirásgyújtés tekintetében, amelyek mögött olyan szervezetek állnak, amelyeknek kiterjedt európai hálózatuk van és képesek a háttérben a folyamatok koordinálására. Ezt a feladatot a MSP esetében a FUEN tökéletesen ellátta.

A szervezők bár már ekkor benyújthatták volna a kezdeményezést azonban ezt csak 2020. január 10-én tették meg. Az ok az volt, hogy a szervezők jobbnak látták megvárni a 2019-es európai parlamenti választásokat, hogy a javaslatukat egy új összetételú Európai Bizottsághoz nyújthassák be. ${ }^{44}$ Az Európai Bizottság 2020. február 5-én találkozott a

\footnotetext{
39 TÁRNOK, 2020. 168.o.

${ }^{40}$ FUEN (3)

${ }^{41}$ Koppenhágai kritériumok: 1) a demokráciát, a jogállam és az emberi jogok érvényesülését garantáló intézmények stabilitása, a kisebbségi jogok tiszteletben tartása és védelme; 2) müködő piacgazdaság és képesség az Unión belüli versenyviszonyokkal és piaci erôkkel való megbirkózásra; 3) a tagsággal járó kötelezettségek teljesítésére - és ennek részeként az uniós jogot képező szabályok, standardok és szakpolitikák (a közösségi vívmányok) hatékony végrehajtására - való képesség, valamint a politikai, gazdasági és monetáris unió célkitűzéseinek vállalása

42 Bulgária, Dánia, Horvátország, Lettország, Litvánia, Magyarország, Olaszország, Románia, Spanyolország, Szlovákia, Szlovénia

43 TÁRNOK, 2020. 12.o.

44 JоÓB, 2019.
} 
szervezőkkel. ${ }^{45}$ Ezt követően kellett 2020. október 15-én a szervezők egy nyilvános meghallgatáson bemutassák a kezdeményezést és az abban található javaslatokat az Európai Parlamentnek. ${ }^{46}$

Az Európai Parlament a meghallgatás után 2020. december 17-én kellett állást foglaljon az ügyben. Ekkor döntő többséggel 524 igennel, 67 nem szavazattal és 103 tartózkodással az EP elfogadta a MSP-t támogató határozatot. ${ }^{47}$ Ebben az állásfoglalásban az Európai Parlament támogatásáról biztosította a kezdeményezést és felszólította az Európai Bizottságot, hogy terjesszen elő jogalkotási javaslatokat. Ennek keretében az EP arra kérte az Európai Bizottságot, hogy dolgozza ki a kisebbségekhez tartozó személyek jogainak védelmére vonatkozó uniós szabályok közös keretrendszerét, mindezek mellett a tagállamokat is felszólította, hogy minden szükséges intézkedést tegyenek meg a témakör tekintetében. Ennek a felszólításnak a Bundestag eleget is tett és támogató határozatában arra kérte az Európai Bizottságot, hogy léptesse érvénybe az abban foglaltakat. ${ }^{48}$

A sikeres meghallgatással és az Európai Parlament támogatásával már csak az Európai Bizottság pozitív elbírálására volt szükség. A szervezők és az érintettek joggal voltak bizakodóak a tekintetben, hogy az ekkorra már több mint 8 éve zajló csatározások után végre pozitív elbírálásba fog részesülni a kezdeményezés. Az Európai Bizottság 2021. január 15-ig kellett közzé tegye az álláspontját a MSP kapcsán. Erre a határidő lejárta előtt egy nappal már sor került.

Az Európai Bizottság ezen a napon egy 23 oldalas közleményben ${ }^{49}$ a kezdeményezést elutasította és semmilyen további jogi aktust nem irányzott elő. Mind a 9 kezdeményezés esetében arra a következtetésre jutott, hogy „a már hatályos jogszabályok és szakpolitikai intézkedések teljeskörű végrehajtásával a kezdeményezés célja kellően előmozdíthatóak". A konkrét példa kedvéért vegyük szemügyre a MSP első javaslatát és az arra adott Bizottsági választ. Az első javaslat egy Tanácsi ajánlás megalkotását indítványozza elő, amely a kulturális és nyelvi sokszínúség előmozdítását szolgálná az EU-ban. Eszerint az EU-nak meg kellene határozza a kulturális

\footnotetext{
45 EURÓPAi UNiÓ (1)

46 Európai UNIÓ (2)

48 Hungary Today, 2020.

${ }^{49}$ BizotTsáG, 2021.
} 
és nyelvi sokszínűség védelmének módját számos területen. ${ }^{50}$ Erre a Bizottság a válaszában utal az EUSZ 2. cikkére ${ }^{51}$, amely kimondja, hogy a kisebbségekhez tartozó személyek jogainak tiszteletben tartása az Unió egyik alapértéke, valamint az Alapjogi Charta 21. és 22. cikkére ${ }^{52}$, amely tiltja a kisebbséghez tartozás alapján történő megkülönböztetést. Ezek mellett még meglévő illetve folyamatban lévő kezdeményezésekre utal, mint amilyen az 1992-es Európa Tanács által kiadott Regionális vagy Kisebbségi Nyelvek Európai Kartájasa a 2005-ös UNESCO kulturális kifejezések sokszínűségének védelmérôl és előmozdításáról szóló egyezménye ${ }^{54}$, a közös értékek, az inkluzív oktatás és az oktatás európai dimenziójának előmozdításáról szóló tanácsi ajánlás ${ }^{55}$, a nyelvtanítás és nyelvtanulás átfogó megközelítéséről szóló tanácsi ajánlás ${ }^{56}$, az európai oktatási térség 2025-ig történő megvalósításáról szóló bizottsági közlemény ${ }^{57}$, valamint a romák esélyegyenlőségének, társadalmi befogadásának és részvételének előmozdítását célzó 2020 és 2030 közötti időszakra szóló uniós stratégiai keretrendszer $^{58}$. A Bizottság indoklásában a felsorolt jogi eszközök már meglévő intézkedéscsomagnak tekinthetők, így nem irányoz elő külön jogi javaslatot, amellyel közvetlenül segíteni tudná az ajánlásban megfogalmazott célokat. Az Európai Bizottság a döntésének az indoklásában nincs arra kötelezve, hogy a jogi és politikai szempontok elkülönüljenek egymástól, azonban lehetővé kell tegye, hogy azok maguktól érthetődőek legyenek. Ennek a 23 oldalas elutasító közlemény igen csekély mértékben tesz eleget. Ahogy a fenti példa is bemutatja, azt olvashatjuk ki a dokumentumból, hogy az Európai Bizottság egyértelmûvé tette, hogy számára semmilyen

50 Közigazgatásban, közszolgáltatásban, oktatásban, kultúrában, igazságszolgáltatásban, médiában, egészségügyben, kereskedelemben és fogyasztóvédelemben.

51 EURÓPAI UNIÓ, AZ EURÓPAI UNIÓRÓL SZÓLÓ SZERZŐDÉS EGYSÉGES SZERKEZETBE FOGLALT VÁLTOZATA, 2012.

52 Európai Unió, AZ EuróPAi unió Alapjogi Chartája, 2016.

53 EURÓPA TANÁCS, 1998.

54 UNESCO, 2008. ÉVI VI. TÖRVÉNY

55 TANÁCS, A TANÁCS AJÁNLÁSA A KÖZÖS ÉRTÉKEK, AZ INKLUZÍV OKTATÁS ÉS AZ OKTATÁS EURÓPAI DIMENZIÓJÁNAK ELÖMOZDÍTÁSÁRÓL, 2018.

56 TANÁCS, A TANÁCS AJÁNLÁSA A NYELVTANÍTÁS ÉS A NYELVTANULÁS ÁTFOGÓ MEGKÖZELÍTÉSÉRŐL, 2018.

${ }^{57}$ BizotTság, A BizotTsÁg KÖZlemÉnYe az Európai ParlamentneK, A TANÁCSNAK, AZ EuRÓPAi GAZDASÁgI ÉS SZOCIÁlis BizOTTSÁGNAK ÉS A RÉGIÓK BizOTTSÁGÁNAK AZ EURÓPAI OKTATÁSI TÉRSÉG 2025-IG TÖRTÉNŐ MEGVALÓSÍTÁSÁRÓL, 2020.

58 BIZOTTSÁG, A ROMÁK EGYENLŐSÉGE, VALAMINT TÁRSADALMI BEFOGADÁSA ÉS RÉSZVÉTELE AZ EU-BAN, 2020. 
prioritással nem bír az őshonos nemzeti kisebbségek védelme az Európai Unióban és csupán nem kötelező érvényű Európa Tanács által meghozott ajánlásokra hivatkozva utalt arra, hogy a jelenlegi szabályozási rendszer megfelelő védelmet biztosít. Ahogyan az ügy jogi szempontú értékelése rámutat $^{59}$, az Európai Bizottságnak lenne hatásköre a nemzeti és nyelvi kisebbségekhez tartozó személyek védelmének növelését célzó javaslatot tenni, a saját hatásköre alá tartozó területeken kiegészítő jogalkotási javaslat formájában és éppen evégett nem hivatkozott a hatáskör hiányára.

\section{AZ EURÓPAI BIZOTTSÁG ÁLLÁSPONTJÁNAK KRITIKÁJA}

Mielőtt ennek az értékelésére és esetleges okaira rátérnénk szükségesnek ítélem az eddigi MSP-en kívül öt másik sikeres polgári kezdeményezés rövid bemutatását és azok eredményeinek ismertetését. Ezek ismerete ugyanis szükséges a megfelelő konklúziók levonása előtt. Így röviden, egységes pontokba szedve a következőkben öt kezdeményezésről lesz szó.

Az első kezdeményezés címe „Tiltsák be a glifozátot, és védjék meg az embereket és a környezetet a mérgező növényvédő szerektől”. ${ }^{60}$ Ezt a kezdeményezést 1.070 .865 ember támogatta és a célja a glifozát tartalmú növényvédő szerek betiltására irányult, amely szer összefüggésbe hozható a rák kialakulásával az emberi szervezetben, továbbá egy növényvédőszermentes jövő megalkotására kérték fel az Európai Bizottságot. Utolsó kérésként arra szólították fel az Európai Bizottságot, hogy csak olyan növényvédő szerek kerülhessenek forgalomba, amelyek jóváhagyása olyan tanulmányokon alapul, amit az illetékes közigazgatási szervek rendeltek el nem pedig a növényvédőszer-ágazat. Az Európai Bizottság a glifozát betiltása tekintetében nem nyújtott be jogalkotási javaslatot, azonban a másik két cél esetében az egyikben jogalkotási javaslat előterjesztésére kötelezte el magát valamint kijelentette, hogy kiemelt figyelmet fognak fordítani a probléma orvoslása érdekében. ${ }^{61} \mathrm{Az}$ ebből a kezdeményezésből

\footnotetext{
59 TÁRNOK, 2021.

${ }^{60}$ Európai Unió, Tiltsák be a glifozátot, és védjék meg az embereket és a környezetet a mérgező növényvédő szerektől!

${ }^{61}$ EUROPEAN COMISSION, COMMUNICATION FROM THE COMMISSION ON THE EUROPEAN Citizens' INITIATIVE "BAN GLYPHOSATE AND PROTECT PEOPLE AND THE ENVIRONMENT FROM TOXIC PESTICIDES", 2017.
} 
származó rendelet 2021. március 27-én válik alkalmazandóvá. ${ }^{62}$ Tehát kijelenthetjük, hogy az Európai Bizottság a káros növényvédőszer szabályozásának területén együttmúködött a szervezőkkel és meghallgatta több mint egymillió ember kérését.

A második kezdeményezés címe „Stop vivisection". ${ }^{3}$ Ezt a kezdeményezést 1.173 .130 ember támogatta és a célja olyan jogi keret megalkotására irányult, amely megvalósítja az állatkísérletek fokozatos megszüntetését. Az Európai Bizottság a kezdeményezés hatására 2015. június 3-án olyan közleményt ${ }^{64}$ fogadott el, amely felvázolta, hogy milyen intézkedéseket szándékszik tenni a kezdeményezés céljainak megvalósítása érdekében. Ennek következményeként 2016. december 6-7-én tudományos konferencia került megszervezésre Brüsszelben, amelynek témája az állatokon végzett tesztelés alternatívájának megtalálására irányult. ${ }^{65}$ Tehát elmondhatjuk, hogy az Európai Bizottság az állatokon végzett kísérletek alternatíva keresése tekintetében együttműködő volt a szervezőkkel és meghallgatta több mint egymillió ember kérését.

A harmadik kezdeményezés címe „Egy közülünk”. ${ }^{66}$ Ezt a kezdeményezést 1.721.626 ember támogatta és a célja az volt, hogy az Európai Unió tiltsa be az összes olyan tevékenység anyagi támogatását, amelyekben feltételezhetően emberi embriók megsemmisítése történik. A kezdeményezők különösen a kutatás, fejlesztés és a közegészségügy területeit emelték ki. Kérésüket azzal támasztották alá, hogy az emberi méltóság, az élethez való jog minden ember integritásának jogi védelme a fogantatástól kezdve, valamennyi területen uniós hatáskörbe tartozik. Az Európai Bizottság e tekintetben 2014. május 28-án kiadott közleményében ${ }^{67}$ arra jutott, hogy nem nyújt be jogalkotási javaslatot mert a meglévő támogatási keret helyes és az Európai Parlamentben nemrégiben megbeszéléseket folytattak erről és döntöttek a szükséges intézkedésről.

62 Tanács, A. E., Az Európai Parlament és A TANÁcs (EU) 2019/1381 Rendelete (2019. JÚNIUS 20.) AZ ÉLELMISZERLÁNCBAN ALKALMAZOTT UNIÓS KOCKÁZATÉRTÉKELÉS ÁTLÁTHATÓSÁGÁRÓL ÉS FENNTARTHATÓSÁGÁRÓL, TOVÁBBÁ A 178/2002/EK, AZ 1829/2003/EK, AZ 1831/2003/EK,, 2019.

${ }^{63}$ EURÓPAI UNIÓ, STOP VIVISECTION.

${ }^{64}$ European COMISSION, COMMUNiCATION From THE COMMISSION ON THE EUROPEAN Citizens' Initiative "STOP Vivisection", 2015.

${ }^{65}$ Cronin, 2017.

${ }^{66}$ EURÓPAI UNIÓ, EGY KÖZÜLÜNK.

${ }^{67}$ European COMISSION, COMMUNICATION FROM THE COMMISSION ON THE EUROPEAN Citizens' Initiative "ONE OF Us", 2014. 
Tehát elmondhatjuk, hogy az Európai Bizottság az emberi embriókon folytatott kísérletek megszüntetésére irányuló kezdeményezés szervezőivel nem múködött együtt, ebben az esetben nem hallgatták meg a majdnem kétmillió ember kérését.

A negyedik kezdeményezés címe „A Víz és a szennyvízhálózat emberi jog! A Víz egy nyilvános jó, nem árucikk!’68 Ezt a kezdeményezést 1.659.543 ember támogatta és a céljukat három pontban fogalmazták meg. Az első, hogy az uniós intézmények kötelesek legyenek minden lakos számára a vízhez és a szennyvízhálózathoz való hozzáférést biztosítani. A második pont, hogy a vízkészlet és annak a kezelése ne legyen belső piaci szabályozásnak alávetve. A harmadik pontban pedig arra kérték az EU-t, hogy növelje meg az erőfeszítését a tekintetben, hogy a vízhez és a szennyvíz hálózathoz való hozzáférés univerzális legyen. Az Európai Bizottság hét pontban reagált és fogalmazott meg területeket amelyen cselekvésre szánta el magát. ${ }^{69}$ E kezdeményezés hatására az Európai Bizottság 2018. február 1-jén elfogadta az ivóvízről szóló irányelv felülvizsgálatára vonatkozó javaslatát. ${ }^{70}$ Ezt követően 2018. májusában rendeletjavaslatot fogadott el a víz újrafelhasználására vonatkozó minimumkövetelményekről. ${ }^{71}$ Tehát elmondhatjuk, hogy a Bizottság együttmúködött a víz és szennyvízhálózat elterjesztése tekintetében a szervezőkkel és meghallgatta több mint másfélmillió ember kérését.

Az ötödik kezdeményezés címe „Vessünk véget a ketreces állattenyésztésnek!' ${ }^{72}$ Ezt a kezdeményezést 1.397 .113 ember támogatta és a céljaikat négy pontban fogalmazták meg. Az első, hogy tiltsák be a ketrecet a tojótyúkok, nyulak, jércék, brojler tenyészállatok, fürjek, kacsák és libák tartásának esetében. A második, hogy tiltsák be a kocáknak kialakított fialó rekeszeket. A harmadik, hogy tiltsák be a kocaállásokat. A negyedik pedig,

\footnotetext{
${ }^{68}$ EURÓPAI UNIÓ, A VíZ ÉS A SZENNYVÍZHÁLÓZAT EMBERI JOG! A VÍZ EGY NYILVÁNOS JÓ, NEM ÁRUCIKK!

69 Európai BizotTsÁG, A BIZOTTSA $\square$ G KƠZLEME $\square$ NYE A „MindEN EMBERNEK JOGA VAN A VÍZHEZ ÉS A MEGFELELŐ HIGIÉNÉS KÖRÜLMÉNYEKHEZ! A VÍZ KÖZJÓ, NEM ÁRUCIKK!" EURÓPAI POLGÁRI KEZDEMÉNYEZÉSRŐL, 2014.

${ }^{70}$ European Comission, Proposal for a directive of the European Parliament AND OF THE COUNCIL ON THE QUALITY OF WATER INTENDED FOR HUMAN CONSUMPTION (RECAST), 2018.

71 European Comission, Proposal for a regulation of the European PARLIAMENT AND OF THE COUNCIL ON MINIMUM REQUIREMENTS FOR WATER REUSE, 2018.

72 Európai Unió, END the CAge Age
} 
hogy tiltsák be a borjúbokszokat. Az Európai Bizottság a válaszában ${ }^{73}$ arról tájékoztatta a szervezőket, hogy 2023 végéig jogalkotási javaslatot terjeszt elő a ketrecrendszerek használatának fokozatos megszüntetésére és végleges betiltására a kezdeményezésben említett valamennyi állat esetében. Tehát elmondhatjuk, hogy az Európai Bizottság együttműködött a ketrechasználat betiltását követelő szervezőkkel és meghallgatta a több mint egymillió aláíró ember kérését.

Mindezek ismeretében most már értékelhetjük a végeredményt. Ahogy korábban említettük, ezt az elutasítást nem szabad csupán önmagában vizsgálni.

Először is magával az intézményrendszerrel szemben szükséges a kritika megfogalmazása. Az európai polgári kezdeményezés feladata, hogy egy több százmilliós közösség tagjai fel tudják emelni a hangjukat. Az Európai Unió méreténél fogva nem tud olyan jegyekkel és tulajdonságokkal rendelkezni, mint egy ország. Egy országon belül sokkal nagyobb az esélye annak, hogy egy új diszkurzust sikerüljön elindítani. Ennek több oka is van. Egyrészt a mindenkori honi média sokkal jobban és könnyebben fel tud karolni kezdeményezéseket, illetve be tud számolni a polgárok elégedetlenségérôl és ezt nagyon magas hatásfokkal tudja rövid idő alatt sok állampolgárhoz eljuttatni. Továbbá az sem elhanyagolható, hogy a hirtelen, nagy változtatásokat követelő problémákat helyi vagy legalábbis régióspecifikus ok váltja ki. Ezért nagyon értékesek azok a gondolatok, amelyek képesek átívelni országhatárokon és egyszerre több ország állampolgárát képes cselekvésre késztetni. Evégett is kell kiemelt figyelmet fordítani minden olyan kezdeményezésre, amely minden bürokratikus nehézség ellenére eléri és teljesíti a szükséges feltételeket.

Ugyanígy kell nagyra értékelni a MSP kezdeményezést is. Azonban ebben az esetben azért állíthatjuk, hogy sokkal nagyobb figyelmet kellett volna az Európai Bizottságnak erre fordítania, mert e kezdeményezés mögött nem csak több mint egymillió aláíró van, hanem több tízmillió őshonos nemzeti kisebbség is. Ezeknek az embereknek a zöme lehet, hogy éppen azért nem tudja hallatni ma a hangját mert nincsen meg az ehhez szükséges jogi-társadalmi-szociális háttér, amelynek a javítására tett kísérletet a MSP több területen. Ilyen értelemben az Európai Bizottság nem egymillió embernek mondott nemet, hanem több tízmillió saját polgárának.

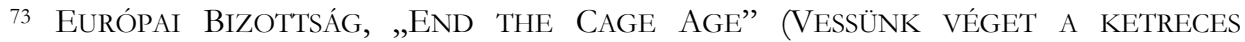
ÁLLATTENYÉSZTÉSNEK!) KEZDEMÉNYEZÉS - VÁLASZINTÉZKEDÉSEK 
Különösen érdekes az Európai Parlament és az Európai Bizottság közötti ellentét, amely a támogatás kérdésében jól látható különbséget produkált. Az Európai Parlament a nemzetek akaratát jeleníti meg, lévén a képviselők mögött valós társadalmi támogatottság van, a legitimitásuk az saját országuk állampolgáraitól közvetlenül eredezik. ${ }^{74}$ Ezzel szemben az Európai Bizottság kizárólag az uniós érdekek előmozdítása érdekében múködik és a tagjainak nincsen valós mérhető társadalmi legitimációja. ${ }^{75}$ Emiatt rendkívül ellentmondásos, hogy egy állampolgári erőfeszítésekkel teli, több éves jogi és politikai küzdelem ellenében is minden feltételnek eleget tevő kezdeményezést az Európai Bizottság gyakorlatilag egyetlen határozatával el tudja lehetetleníteni úgy, hogy jogorvoslati lehetőségnek sincsen helye.

Az Európai Bizottság az elutasító határozatában több helyen utal arra, hogy bizonyos ügyek, amelyek magasabb fokú szabályozása előmozdítaná a kisebbség ügyeit, azok nem tartoznak azon területek közé, amelyeket szabályozhat. Ez a válasz és indoklás mérhetetlenül politikai és cinikus. Az Európai Uniónak, azon belül is talán az Európai Bizottságnak van meg a legnagyobb lehetősége arra, hogy pusztán lobbierejét felhasználva is jelentős változásokat tudjon elérni a kiválasztott területen. Ebből és az elmúlt néhány év történéséből joggal következtetünk arra, hogy az EU egyik legerősebb szerve válogat a politikai értékek között és egyoldalúan dönti el mi számít helyesnek és mi nem. Az elmúlt években sokszor hallhattuk a jogállamiság és a sajtószabadság ügyét. Számtalanszor hangzott el kritika Magyarországgal szemben, hogy „bizonyos” értékeket nem, illetve nem úgy tart be ahogyan ők ezt helyesnek látják. Ha eltekintünk attól, hogy a vád helyes-e vagy helytelen és csupán magának a kritikának a létét vesszük alapul, akkor azt láthatjuk, hogy az Európai Bizottság kiválasztott egy értéket, kreált arról egy standardot, aminek a végrehajtását követeli. Európában azonban a jogállamiság pont ugyanolyan érték, mint az egyenlő bánásmód követelménye. Ezért tehát amikor az egyikről kritikát fogalmaz meg akár egy EP képviselő javaslatára (Sargentini-jelentés) ${ }^{76}$, míg a másik esetében több tízmilliós társadalmi érintettség esetében elutasít akkor az Európai Bizottság valójában politikai döntést hoz.

\footnotetext{
${ }^{74}$ BLUTMAN, 2020. 69-70.o

75 BlutMan, 2020. 77-79.o.

76 A Tanácsot az Európai Unióról szóló szerződés 7. cikke (1) bekezdésének megfelelően az Unió alapértékeinek Magyarország általi súlyos megsértése egyértelmú veszélyének megállapítására felszólító javaslatról, (2017/2131(INL))
} 
Nem lehet elmenni azon történések mellett sem, amelyek aktuálisak és mélyen sértik a kisebbségi jogokat továbbá jelentős törésvonalat eredményeznek a többségi és kisebbségi társadalom között. Romániában, Spanyolországban, Ukrajnában és számos olyan területen aktuális konfliktust jelent e kérdés, mint például a volt Jugoszlávia területe. Ez a felvetés átvezet minket a kisebbségek biztonságpolitikai szemszögü vizsgálatára, ami kiemelten fontos több szempontot figyelembe véve is. ${ }^{77}$ Egyrészt egy etnikai jellegü konfliktus jelentős törésvonalakat tud eredményezni egy országon belül, ami társadalmi kohézió a megbomlásához vezethet. Az asszimilációs törekvések a kisebbségi társadalom körében ellenérzéseket vált ki, amely könnyen eszkalálódhat konfliktussá. Ezt alátámasztja az a tény, hogy a modern Európában, a XX. század végén és a XXI. században is jellemzően a természetükben forrónak tekinthető polgárháborúk többsége e törésvonal mentén eszkalálódott. Ez jellemző főként a Ukrajna és a balkáni országok területén, de a balti országokban élő orosz kisebbség tekintetében is. Az Európai Unió számára jelzésértékűnek kellene legyen az a tény, hogy a saját területén belül és a közvetlen szomszédságában is biztonsági kockázatot jelent a kisebbségvédelem elhanyagolása.

Mindezek miatt nem állja meg a helyét az Európai Bizottság elutasító határozatában az a temérdek mennyiségű hivatkozás, amelyet egyes, már meglévő jogszabályokra és ajánlásokra tettek, mivel nem egy teljesen új, szabályozásra váró területről van szó. A MSP kezdeményezés sem arra irányult, hogy teljesen új jogszabályokra van szükség. Hanem azok javítására-módosítására és mindenekelőtt a már meglévôk betartatására. Magának a kezdeményezésnek nyilvántartásba vétele bizonyitást ad arra, hogy a probléma valós és kiemelt figyelmet érdemelne.

A tisztánlátás érdekében érdemes az Európai Bizottság partneri szándékának a vizsgálatát elvégezni a többi polgári kezdeményezéssel összevetve. Látható, hogy az eddigi öt kezdeményezés közül három esetben eleget tett, illetve előmozdította a polgárok akaratát, illetve kettőben nem. Az látszik, hogy az Európai Bizottság a gilofát ügyét, az állatkísérletek ügyét, valamint a víz és szennyvízhálózat ügyét további jogalkotási szándékkal díjazta. Azonban az emberi embriókkal szembeni magasabb fokú védelmet igénylő kezdeményezés esetében, valamint az őshonos nemzeti kisebbségek helyzetének javítása ügyében elállt a további cselekvéstől.

${ }^{77}$ CSIKI, 2009. 
A fentiek ismeretében fel kell tennünk a kérdést, hogy mi lehet a kezdeményezés további sorsa? - Az RMDSZ az Európai Bizottság döntését egyértelmúen elítélte, Hegedüs Csilla szóvivő szerint ezzel a döntéssel az Európai Bizottság „hátat fordított az őshonos kisebbségeknek, az aláíró állampolgároknak, a nagy többséggel támogató határozatot elfogadó Európai Parlamentnek, több támogató nemzeti kormánynak és régiónak". ${ }^{78}$

Ennek szellemében a szervezők további lépésekre szánták el magukat. A MSP kezdeményező bizottsága ismét a Törvényszék elé viszi az ügyet. Hans Heinrich Hansen és Kelemen Hunor 2021. március 24-én keresetet nyújtottak be, amivel megtámadják az Európai Bizottság korábbi január 15-i elutasító határozatát. Szerintük az Európai Bizottság közleményében súlyos jogi és procedurális hiányosságok vannak. A 9 javaslatból 7 esetben az Európai Bizottság nem tett eleget az indoklási kötelezettségeinek. A MSP képviseletében eljáró kezdeményező bizottság szerint, a megfogalmazott kritikák és érvek lehetőséget biztosíthatnak arra, hogy semmissé nyilváníthassák az elutasító határozatot. Egy azonban biztos, az ügy nem fog egyhamar megoldódni. A Törvényszék végső döntéséig még több év telhet el. Ez azonban az elmúlt 10 év történéseinek ismeretében nem fogja elvenni a kedvét sem a kezdeményezőknek, sem pedig a támogatóknak. Emellett a szervezők még bizakodhatnak, hogy az Európai Parlament az EUMSZ 225. cikke szerint, a parlament tagjainak a többségével újra felkéri az Európai Bizottságot a jogalkotási aktusra irányuló javaslat újbóli előterjesztésére.

Az Európai Bizottság döntése elleni harc mellett, a kezdeményezőknek még egy problémával mindenképp foglalkozniuk kell, amely eddig is beárnyalta a munkásságukat és változtatás hiányában ezután is be fogja. Ez pedig az a diszkurzus, amelyet az egyes uniós tagállamok képviselnek a MSP ellenében, mint például Románia, Szlovákia vagy épp a jelentôs orosz kisebbséggel rendelkező balti államok.

Románia és Szlovákia a kezdeményezés szempontjából kiemelkedik, hiszen 2014-ben a Bizottság oldalán léptek be a bírósági perbe. Wágner Tamás tanulmányában ${ }^{79}$ több esetet is felsorol, amikor a romániai sajtó és értelmiségi kör heves ellenérzésekkel nyilatkozik a kisebbségvédelmi kezdeményezésről. Ciprian Plaiasu szerint a MSP a Brexitnél is nagyobb fenyegetést jelent, mert többletjogokat biztosítana a kisebbségeknek. Odáig elmegy, hogy a kezdeményezés sikeressége esetén területi autonómiát is ki

\footnotetext{
78 ANTAL - VASS, 2021.

79 WÁGNER, 2018.
} 
tudnának a kisebbségek kényszeríteni, ami az Európai Unió feldarabolásához vezetne. Ionel Grigorescu szerint Románia becsatlakozása a perbe a nemzetállamok védelmében történt, hiszen a kezdeményezés egyértelműen Oroszország érdekeit szolgálja. Ioan Aurel Pop, aki 2018-tól a Román Akadémia elnöke is, az orosz kártyát kijátszva támadta a kezdeményezést és azt állította, hogy a nemzetközinek és semlegesnek álcázott kezdeményezés mögött Moszkva szándékai húzódnak meg. E felvetések csak további bizonyítékként szolgálnak a kisebbségvédelem elhanyagolásának biztonsági kockázataira. Az ilyen és ehhez hasonló felelőtlen, uszító kijelentések meghatározzák a társadalom vélekedését és a mindennapi együttélés szintjén is problémát okoz. A többségi társadalomban beindulhat egy védelmi reflex és elkezdhet ténylegesen úgy tekinteni a kisebbségben élő társaira, mint ami jelentős kockázatként értelmezhető a saját identitására való tekintettel. A kisebbségben élőkben úgyszintén heves ellenreakciók törhetnek elő, hiszen elemében, identitásában érezheti megtámadva magát.

Látható tehát, hogy amellett, hogy bizakodva várni kell az ügy előmenetelét a Törvényszéken, egy legalább akkora súlyú problémával is foglalkozni kell. Főként annak ismeretében, hogy egy újbóli Törvényszéki pozitív elbírálás esetében is, a végső sikerhez a tagállamokat is a kezdeményezés mellé kellene állítani.

\section{KONKLÚZIÓ}

Mint ahogyan a tanulmány címe már utal erre, a MSP egy olyan történet, amely túlmutat önmagán. Ebben az ügyben egyszerre több hiányosság és probléma is lecsapódik. Egyrészt láthatjuk, hogy mindazok a törekvések, amelyek a demokráciadeficit megoldásra irányultak, nem jártak sikerrel. Ez megnyilvánul technikai és szándékbeli hiányosságokban is. Mint ahogyan a tanulmány korábbi részében kifejtésre került alapvetően kódolva volt a jogintézmény múködésébe az érdekek szembenállásából fakadó igazságtalan végeredmény lehetősége. Az a jogintézmény, amely az uniós polgárok érdek artikulációját és aggregációját lehetővé teszi, végeredményben egy olyan testület kezében összpontosul, amely egyöntetűen rendelkezhet felette, elvágva azt minden további lehetőségtől. Másrészt a szándékbeli hiányosságot is ki kell emelni. Sem a korábbi, sem a jelenlegi Európai Bizottságban helyet foglaló személyek nem voltak támogatóak a kezdeményezéssel kapcsolatosan. Még annak ellenére sem, 
hogy a nemzetek érdekeit megjelenítő Európai Parlament és Európa egyik vezetô hatalmának a parlamentje a Bundestag is a pozitív elbírálásra kérte fel. Emögött nehéz nem ideológiai megfontoláson alapuló szándékokat sejteni. Az a mainstream politikai vonulat, amely Nyugat-Európát meghatározza, ellentétes a szilárd alapokon álló, önálló és cselekvő tagállamok elképzeléseivel. Ez a szakadék pedig hova tovább egyre inkább nagyobb lehet az uniós polgárok és az Európai Unió között. Feltehetjük a kérdést, hogy ha több millió kisebbségben élő személy életkörülményeinek előmozdítása és javítása nem jelent kellő súlyt a cselekvési szándék kialakulására, akkor a továbbiakban mi lesz erre képes. Valamint, ahogy a tanulmány több pontban utal rá, a kisebbségvédelem racionális okokból, biztonsági szempontból sem halogatható folyamatosan, hiszen egy önkényes állami döntés vagy egy erőszakos asszimilációs program bármikor eszkalálhat forró konfliktust a többségi és a kisebbségi társadalom tagjai között.

Mi lehet ennek az oka? - Könnyen lehet, hogy a klasszikus integráció mélyítéséről szóló vitának ez ma a modern kori lecsapódása. A két eszme, a föderalizmus és a szuverenizmus összecsapásaként is értékelhetőek az események. Főleg akkor, hogyha egyik másik jövőbeli hatásait próbáljuk feltérképezni. Az őshonos nemzeti kisebbségek támogatása nemzeti érdek, a nemzeti szuverenizmus erősödésének egyik alapköve. Annak gondoskodó elképzelésnek a gyökere, amely szerint felelőséggel tartozunk nemzettársaink felé és a keresztény Európa értékein alapuló cselekvési mechanizmust vetíti elő. A Minority SafePack és az Egy közülünk nevű életvédő kezdeményezés szervező elvei mögött is felsejlenek ezek. Ezekre mondott nemet az Európai Bizottság. Ennek ellenére, az olyan elképzelések támogatást nyertek, amelyek a gilofátot, meg az állatkísérleteket akarták beszüntetni. Ezeknek a sikerességét nem az önmaguk tárgyköre árnyalja. Pusztán az, ahogy az Európai Bizottság különbséget tesz közöttük.

Az Európai Unió jelenleg identitászavarban szenved. Ami ellen küzd és amit elutasított már többedjére, az tulajdonképpen saját maga. Az a több tízmillió személy, aki jelenleg kisebbségben él, az ugyanúgy uniós polgár, mint a többségi társadalom tagjai. Amikor hátat fordít az Európai Unió egy ártani nem kívánó kezdeményezésnek és ezáltal több millió embernek akkor igazából önmagával szemben vív harcot. Azokkal szemben, akik szintén részét képezik a nagy egységnek. Evégett állítja a tanulmány, hogy a MSP többet mond önmagánál. Eddig is többet mutatott és ha az ügy folyatását 
további figyelemmel kísérjük, akkor az a jövőben is hasonlóképpen előre fog vetíteni.

\section{FELHASZNÁLT IRODALOM}

2013. ÉVI CCXXXVIII. TÖRVÉNY A NÉPSZAVAZÁS KEZDEMÉNYEZÉSÉRŐL, AZ EURÓPAI POLGÁRI KEZDEMÉNYEZÉSRŐL, VALAMINT A NÉPSZAVAZÁSI ELJÁRÁSRÓL. (dátum nélk.). Letöltés helye: https://net.jogtar.hu/jogszabaly?docid=a1300238.tv 2021.11.15.)

ANTAL RÓBERT-ISTVÁN, VASS CSABA (2021. 01 15): Körbekérdeztünk az RMDSZ-ben: van, aki lát reményt a Minosrity SafePack-ügybewn, de nem mindenki. Letöltés helye: https://azonnali.hu/cikk/20210115 vanaki-szerint-van-meg-remeny-minority-safepack-ugyben-de-nemmindenki-ilyen-derulato- (Letöltve: 2021.11.15.)

ArATó KriszTA, Lux ÁGNES (2012). Az Európai Unió alkotmányozási kísérlete. In Jakab András, \& Körösényi András: Alkotmányozás Magyarországon és máshol, MTA TKPI, Budapest. Letöltés helye: https://politikatudomany.tk.hu/uploads/files/archived/1261 0 Alkotm anyozas Magyarorszagon II 6.pdf (Letöltve: 2021.11.15.)

ÁSVÁNYI ZSÓFIA (2011): A demokratikus deficit kérdése az Európai Unióban. In Tudásmenedzsment: A Pécsi Tudományegyetem TTK Felnőttképzési és Emberi Erőforrás Fejlesztési Intézetének periodikája, Pécsi Tudományegyetem.

Az EuRópai PARLAMENT ÉS A TANÁCS (2011): Az Európai Unió Hivatalos Lapja. Letöltés helye: $\underline{\text { https://eur- }}$ lex.europa.eu/LexUriServ/LexUriServ.do?uri=OJ:L:2011:065:0001:0022: hu:PDF (Letöltve: 2021.11.15.)

BÁLINT JÓZSEF (2009): Új ütemterv az EU alkotmányának ratifikációjára 2007/2. Letöltés helye: https://jegyzo.hu/uj-utemterv-az-eualkotmanyanak-ratifikaciojara-20072/ (Letöltve: 2021.11.15.)

BLuTMAN LÁSZló (2020) Az Európai Bizottság (Bizottság). In Az Európai Unió joga a gyakorlatban - A Brexit után, HVGOrac, Budapest

CRONIN, MARK (2017): Non-animal approaches the way forward. Letöltés helye:

https://ec.europa.eu/environment/chemicals/lab animals/3r/pdf/scie ntific conference/non animal approaches conference report.pdf (Letöltve: 2021.11.15.) 
CsIKI TAMÁs (2009): Egység a sokféleségben. Nemzet és Biztonság, 2009/9. szám.

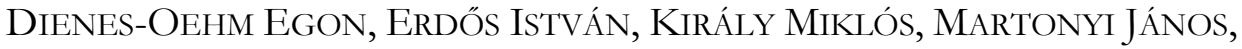
SOMSSICH RÉKA, \& SZABADOS TAMÁS (2014): Az Európai Unió gazdasági joga I. A belső piac és a közös kereskedelempolitika. Budapest: ELTE Eötvös Kiadó.

EPLÉNYI KATA (2013): A Nemzeti kisebbségek védelme az Európai Unióban. Létünk 2013/különszám, 44-54.

EURÓPA TANÁCS (1998): 1999. évi XL. törvény a Strasbourgban, 1992. november 5-én létrehozott Regionális vagy Kisebbségi Nyelvek Európai Kartájának kihirdetéséről. Letöltés helye: https://net.jogtar.hu/jogszabaly?docid=99900040.TV\#lbj0ida379

(Letöltve: 2021.11.15.)

EURÓPAI BIZOTTSÁG (2021): A Bizottság közleménye a „Minority SafePack - egymillió aláírás a sokszínű Európáért” elnevezésű európai polgári kezdeményezésrôl. Letöltés helye: https://ec.europa.eu/transparency/regdoc/rep/3/2021/HU/C-2021171-F1-HU-MAIN-PART-1.PDF (Letöltve: 2021.11.15.)

EuRÓPAi BizOTTSÁG (2020): A Bizottság közleménye az Európai Parlamentnek a Tanácsnak, az Európai gazdasági és Szociális Bizottságnak és a Régiók Bizottságának az európai oktatási térség 2025-ig történő megvalósításáról. Letöltés helye: https://eurlex.europa.eu/LexUriServ/LexUriServ.do?uri=COM:2020:0625:FIN:HU :PDF (Letöltve: 2021.11.15.)

EuRÓPAi BizotTSÁG (2014): A Bizottság közleménye a „Minden embernek joga van a vízhez és a megfelelő higiénés körülményekhez! A víz közjó, nem árucikk!” európai polgári kezdeményezésről. Letöltés helye: https://ec.europa.eu/transparency/regdoc/rep/1/2014/HU/1-2014177-HU-F1-1.Pdf (Letöltve: 2021.11.15.)

EuróPAi BIZOTTSÁG (dátum nélk.): „End the Cage Age” (Vessünk véget a ketreces állattenyésztésnek!) kezdeményezés - válaszintézkedések. Letöltés helye: https://europa.eu/citizens-initiative/end-cage-agefollow hu (Letöltve: 2021.11.15.)

EURÓPAi BizOTTSÁG (2020): Teljes körű befogadás: A Bizottság bemutatja az integrációról és a befogadásról szóló, a 2021-2027-es időszakra vonatkozó cselekvési tervet. Letöltés helye: https://ec.europa.eu/commission/presscorner/detail/hu/IP $20 \quad 2178$ (Letöltve: 2021.11.15.) 
Európai PARLAMENT (dátum nélk.): Az Európai Alkotmányt létrehozó szerződés tervezete (nem ratifikált szerződés). Letöltés helye: europarl.europa.eu: $\quad$ https://www.europarl.europa.eu/aboutparliament/hu/in-the-past/the-parliament-and-the-treaties/draft-treatyestablishing-a-constitution-for-europe (Letöltve: 2021.11.15.)

EURÓPAi PARLAMENT (2005): Európai Alkotmány - Áttekintés. Letöltés helye: https://www.europarl.europa.eu/sides/getDoc.do?pubRef=$\angle / \mathrm{EP} / / \mathrm{NONSGML}+\mathrm{IM}-$

$\underline{\mathrm{PRESS}}+20050819 \mathrm{FCS} 00974+0+\mathrm{DOC}+\mathrm{PDF}+\mathrm{V0} / / \mathrm{HU} \&$ language $=\mathrm{HU}$ (Letöltve: 2021.11.15.)

EURÓPAI POLGÁRI KEZDEMÉNYEZÉS (dátum nélk.). Letöltés helye: https://www.europarl.europa.eu/at-your-service/hu/be-heard/citizen-sinitiative (Letöltve: 2021.11.15.)

EURÓPAI UnIÓ (2016): Az Európai Unió Alapjogi Chartája. Letöltés helye: https://eur-lex.europa.eu/legal-

content/HU/TXT/?uri $=$ celex $\% 3 \mathrm{~A} 12016 \mathrm{P} \% 2 \mathrm{FTXT}$

(Letöltve: 2021.11.15.)

EURÓPAI UNIÓ (2012): Az Európai Unióról szóló szerződés egységes szerkezetbe foglalt változata. Letöltés helye: https://eurlex.europa.eu/resource.html?uri=cellar:2bf140bf-a3f8-4ab2-b506fd71826e6da6.0007.02/DOC 1\&format=PDF (Letöltve: 2021.11.15.)

EURÓPAI UNIÓ (1) (dátum nélk.). Benyújtás és vizsgálat. Letöltés helye: europa.eu: https://europa.eu/citizens-initiative/minority-safepack-onemillion-signatures-diversity-europe hu (Letöltve: 2021.11.15.)

EURÓPAI UNIÓ (dátum nélk.). Egy közülünk. Letöltés helye: https://europa.eu/citizens-initiative/one-us hu (Letöltve: 2021.11.15.) Európai Unió. (dátum nélk.). End the Cage Age. Letöltés helye: https://europa.eu/citizens-initiative/initiatives/details/2018/000004 hu (Letöltve: 2021.11.15.)

EURÓPAi UNIÓ (2) (dátum nélk.). Minority SafePack - Egymillió aláírás a sokszínú Európáért. Letöltés helye: https://europa.eu/citizensinitiative/minority-safepack-one-million-signatures-diversityeurope hu\#Az-Europai-Bizottsag-valasza-es-nyomon-kovetes (Letöltve: 2021.11.15.)

EURÓPAI UNIÓ (dátum nélk.): Stop vivisection. Letöltés helye: https://europa.eu/citizens-initiative/stop-vivisection hu (Letöltve: 2021.11.15.) 
EURÓPAI UNIÓ (dátum nélk.): Tiltsák be a glifozátot, és védjék meg az embereket és a környezetet a mérgező növényvédő szerektől! Letöltés helye: $\quad$ https://europa.eu/citizensinitiative/initiatives/details/2017/000002 hu (Letöltve: 2021.11.15.)

EURÓPAi UNIÓ (dátum nélk.). A Víz és a szennyvízhálózat emberi jog! A Víz egy nyilvános jó, nem árucikk! Letöltés helye: https://europa.eu/citizens-initiative/initiatives/details/2012/000003 hu (Letöltve: 2021.11.15.)

EuROPEAN COMISSION (2017): Communication from the Commission on the European Citizens' Initiative "Ban glyphosate and protect people and the environment from toxic pesticides". Letöltés helye: https://ec.europa.eu/transparency/regdoc/rep/3/2017/EN/C-20178414-F1-EN-MAIN-PART-1.PDF (Letöltve: 2021.11.15.)

EUROPEAN COMISSION (2014): Communication from the Commission on the European Citizens' Initiative "One of us". Letöltés helye: https://ec.europa.eu/transparency/regdoc/rep/1/2014/EN/1-2014355-EN-F1-1.Pdf (Letöltve: 2021.11.15.)

EUROPEAN COMISSION (2015): Communication from the Commission on the European Citizens' Initiative "Stop Vivisection". Letöltés helye: https://ec.europa.eu/transparency/regdoc/rep/3/2015/EN/3-20153773-EN-F1-1.PDF (Letöltve: 2021.11.15.)

European Comission (2018): Proposal for a Directive of the European Parliament and of the Council on the quality of water intended for human consumption (recast). Letöltés helye: https:/ / ec.europa.eu/environment/water/waterdrink/pdf/revised drinking water directive.pdf (Letöltve: 2021.11.15.)

European Comission (2018): Proposal for a Regulation of the European Parliament and of the Council on minimum requirements for water reuse. Letöltés helye: https://ec.europa.eu/environment/water/pdf/water reuse regulation.p df (Letöltve: 2021.11.15.)

FELVIDÉK.MA (2014): Szlovákia után Románia is az Európai Bizottság oldalán lépett be a kisebbségek luxemburgi perébe. Letöltés helye: https://felvidek.ma/2014/07/szlovakia-utan-romania-is-az-europaibizottsag-oldalan-lepett-be-a-kisebbsegek-luxemburgi-perebe/ (Letöltve: 2021.11.15.)

FUEN (1) (dátum nélk.): Tagszervezeteink listája. Letöltés helye: fuen.org: https://www.fuen.org/hu/members (Letöltve: 2021.11.15.) 
FUEN (2) (dátum nélk.): A FUEN története. Letöltés helye: https://www.fuen.org/hu/article/A-FUEN-toertenete (Letöltve: 2021.11.15.)

FUEN (3) (dátum nélk.). Minority SafePack Initiative. Letöltés helye: http://www.minority-

safepack.eu/assets/downloads/booklet/MSPI brochure HU.pdf (Letöltve: 2021.11.15.)

Gyergyai CsabA, VÁSÁRHELYI-NYEMEC RÉKA (2013): Az Európai Bizottság elutasította az RMDSZ kisebbségvédelmi polgári kezdeményezését (bővítve) Letöltés helye: https://kronikaonline.ro/erdelyi-hirek/az-europai-bizottsag-elutasitottaaz-rmdsz-kisebbsegvedelmi-polgari-kezdemenyezeset-bovitve (Letöltve: 2021.11.15.)

Hungary Today (2020): German Bundestag Backs Minority SafePack Initiative and Appeals to EC. Letöltés helye: hungarytoday.hu: https://hungarytoday.hu/german-bundestag-minority-safepackinitiative-appeal-ec-fuen/ (Letöltve: 2021.11.15.)

JOÓB KRISTÓF (2019): Az új Bizottságtól függ az európai nemzeti kisebbségek védelme. Letöltés helye: precedens.mandiner.hu: https://precedens.mandiner.hu/cikk/20190927 az uj bizottsagtol fugg az europai nemzeti kisebbsegek vedelme (Letöltve: 2021.11.15.)

MAGYARKOLlÉGIUM.HU (dátum nélk.). Miről szól az EU Alkotmány? (Információk, ismertetô). Letöltés helye: http://www.magyarkollegium.hu/pdf/torveny eu3.pdf (Letöltve: 2021.11.15.)

MANZINGER KRISZTiÁN, VinCZE LÓRÁNT (dátum nélk.): Minority SafePack - Esély az EU-s kisebbségvédelemre? In Kisebbségvédelem az EU-ban

MARJÁN AtTILA, Boros LuCA (2017): Az állampolgárság, nép, nemzet alkotmányozás és föderalizmus értelmezési nehézségei az Európai Unióban.Pro Publico Bono, Ludovika Egyetemi Kiadó, Budapest.

MEDINA VIKTOR (2011): EU ismeretek. Szent István Egyetem, Budapest „MINORITY SAFEPACK - EGYMILLIÓ ALÁíRÁS A SOKSZÍNÜ EURÓPÁÉRT” ELNEVEZÉSŰ JAVASOLT POLGÁRI KEZDEMÉNYEZÉSRŐL, (EU) 2017/652 határozata, Európai Bizottság 2017. 0319.

PARLAMENT (2021): A Lisszaboni Szerződés. Letöltés helye: https://www.europarl.europa.eu/factsheets/hu/sheet/5/a-lisszaboniszerzodes (Letöltve: 2021.11.1.5) 
Stibbe, Timo - Taner, Hande (2019): The Dutch and French Nos tot he Referenda ont he Treaty Establishing a Constitution for Europe, SciencesPo Biblothéque. Letöltés helye: http://dossiersbibliotheque.sciencespo.fr/une-vie-politique-europeenne-europeanpolitical-life/dutch-and-french-nos-referenda-treaty

(Letöltve: 2021.11.15.)

TANÁCS, A. E. (2019): Az Európai Parlament és a Tanács (EU) 2019/1381 rendelete (2019. június 20.) az élelmiszerláncban alkalmazott uniós kockázatértékelés átláthatóságáról és fenntarthatóságáról, továbbá a 178/2002/EK, az 1829/2003/EK, az 1831/2003/EK,. Letöltés hellye: eur-lex.europa.eu: $\quad \underline{\text { https://eur-lex.europa.eu/legal- }}$ content/HU/TXT/PDF/?uri=CELEX:32019R1381 (Letöltve: 2021.11.15.)

TANÁCs (2018): A Tanács ajánlása a nyelvtanítás és a nyelvtanulás átfogó megközelítéséről. Letöltés helye: https://eur-lex.europa.eu/legalcontent/HU/TXT/?uri=CELEX\%3A52018DC0272 (Letöltve: 2021.11.15.)

TANÁCS (2018): A TANÁCS AJÁNLÁSA a közös értékek, az inkluzív oktatás és az oktatás európai dimenziójának előmozdításáról. Letöltés helye: eur-lex.europa.eu: $\quad$ https://eur-lex.europa.eu/legalcontent/HU/TXT/PDF/?uri=CELEX:32018H0607(01)\&from=DE (Letöltve: 2021.11.15.)

TÁRNOK BALÁZS (dátum nélk.): Kisebbségvédelem az Európai Unióban.

TÁRNOK BALÁZS (2020): Az európai polgári kezdeményezés különös tekintettel a nemzeti kisebbségek jog- és érdekvédelmére. Pázmány Péter Katolikus Egyetem, Jog- és Államtudományi Doktori Iskola, Budapest

TÁRNOK BALÁzs. (2021): Az Európai Bizottság lesöpörte az asztalról a Minority SafePack kisebbségvédelmi kezdeményezést. Budapest: Nemzeti Közszolgálati Egyetem.

UNESCO (2008. évi VI. törvény): 2008. évi VI. törvény a kulturális kifejezések sokszínűségének védelméről és előmozdításáról szóló, Párizsban 2005. év október hó 20. napján elfogadott UNESCO egyezmény kihirdetéséről. Letöltés helye: net.jogtár.hu: https://net.jogtar.hu/jogszabaly?docid=a0800006.tv $\quad$ (Letöltve: 2021.11.15.)

VARGA PÉTER, TÁRNOK BALÁZs (2017): Európai polgári kezdeményezések a nemzeti kisebbségek védelmében. In Kisebbségi Szemle, Nemzetpolitikai Kutatóintézet, Budapest. 
WÁGNER TAMÁs ZOLTÁN (2018): A román nemzetpolitikai útjai, különös tekintettel a Minority SafePack kezdeményezés megítélésére in. Magyarok jogvédelme a Kárpát-medencében, Kisebbségi Jogvédő Intézet, Budapest 